Article

\title{
Pyrite Textures, Trace Elements and Sulfur Isotope Chemistry of Bijaigarh Shales, Vindhyan Basin, India and Their Implications
}

\author{
Indrani Mukherjee ${ }^{1, *(\mathbb{D})}$, Mihir Deb ${ }^{2}$, Ross R. Large ${ }^{1}$, Jacqueline Halpin ${ }^{3}$, Sebastien Meffre ${ }^{1} \mathbb{D}$, \\ Janaína Ávila ${ }^{4}$ and Ivan Belousov ${ }^{1}$ \\ 1 Centre for Ore Deposit and Earth Sciences (CODES), University of Tasmania, Hobart, TAS 7001, Australia; \\ ross.large@utas.edu.au (R.R.L.); sebastien.meffre@utas.edu.au (S.M.); ivan.belousov@utas.edu.au (I.B.) \\ 2 Department of Geology, University of Delhi, New Delhi 110021, India; mihirdeb@gmail.com \\ 3 Institute for Marine and Antarctic Studies, University of Tasmania, Battery Point, TAS 7004, Australia; \\ jacqueline.halpin@utas.edu.au \\ 4 Research School of Earth Sciences, The Australian National University, Canberra, ACT 2601, Australia; \\ janaina.avila@anu.edu.au \\ * Correspondence: indrani.mukherjee@utas.edu.au
}

Received: 15 May 2020; Accepted: 22 June 2020; Published: 29 June 2020

\begin{abstract}
The Vindhyan Basin in central India preserves a thick $(\sim 5 \mathrm{~km})$ sequence of sedimentary and lesser volcanic rocks that provide a valuable archive of a part of the Proterozoic ( 1800-900 Ma) in India. Here, we present an analysis of key sedimentary pyrite textures and their trace element and sulfur isotope compositions in the Bijaigarh Shale (1210 $\pm 52 \mathrm{Ma})$ in the Vindhyan Supergroup, using reflected light microscopy, LA-ICP-MS and SHRIMP-SI, respectively. A variety of sedimentary pyrite textures (fine-grained disseminated to aggregates, framboids, lags, and possibly microbial pyrite textures) are observed reflecting quiet and strongly anoxic water column conditions punctuated by occasional high-energy events (storm incursions). Key redox sensitive or sensitive to oxidative weathering trace elements $(\mathrm{Co}, \mathrm{Ni}, \mathrm{Zn}, \mathrm{Mo}, \mathrm{Se})$ and ratios of $(\mathrm{Se} / \mathrm{Co}, \mathrm{Mo} / \mathrm{Co}, \mathrm{Zn} / \mathrm{Co})$ measured in sedimentary pyrites from the Bijaigarh Shale are used to infer atmospheric redox conditions during its deposition. Most trace elements are depleted relative to Proterozoic mean values. Sulfur isotope compositions of pyrite, measured using SHRIMP-SI, show an increase in $\delta^{34} \mathrm{~S}$ as we move up stratigraphy with positive $\delta^{34} \mathrm{~S}$ values ranging from $5.9 \%$ o (lower) to $26.08 \%$ o (upper). We propose limited sulphate supply caused the pyrites to incorporate the heavier isotope. Overall, we interpret these low trace element signatures and heavy sulfur isotope compositions to indicate relatively suppressed oxidative weathering on land during the deposition of the Bijaigarh Shale.
\end{abstract}

Keywords: Bijaigarh Shale; pyrite; Middle Proterozoic; SHRIMP-SI; LA-ICP-MS

\section{Introduction}

Several Paleo-Mesoproterozoic and some Neoproterozoic intracratonic basins with thick platformal siliciclastic-carbonate lithologies cover extensive parts of peninsular India. The largest amongst these is the Vindhyan Basin in the Northern Cratonic Block of the peninsular shield (Figure 1 inset). This basin in Central India, comprises a dominantly flat-lying, undeformed and unmetamorphosed sedimentary package (including some volcanics) that wrap around the Archean $(>2.5 \mathrm{Ga})$ Bundelkhand massif in a semicircle to the north and abut against the Paleoproterozoic Aravalli orogenic belt to the northwest, the Cretaceous Deccan Traps to the southwest and the Paleoproterozoic rocks of the Satpura mobile belt in the southeast. Structurally, the basin is divided into a number of sub-basins, the biggest amongst which are the Rajasthan sector in the west and Son Valley sector in Uttar Pradesh-Madhya 
Pradesh-Bihar in the east (Figure 1). In this large space-time framework, spanning from $\sim 1800$ to $\sim 900 \mathrm{Ma}$ [1-3], the basin witnessed supercontinental cycles (including apparent polar wandering), volcanic activity, episodic igneous intrusions, formation of mineral deposits and evolution of complex life forms, that has prompted multidisciplinary research in the basin [3-8].

The Vindhyan Basin provides an excellent opportunity to probe the concentration of redox sensitive elements in carbonaceous horizons towards understanding oceanic-atmospheric oxygenation patterns in the Middle Proterozoic, (or part of a period known as the "Boring Billion" [9]). Specifically, organic matter-rich stratigraphic intervals, such as black shales/mudstones are most suitable for this purpose. Previous studies have demonstrated how redox sensitive elements in black shales can be used as paleoenvironmental indicators [10-15]. Black shales also allow application of certain geochronological techniques, such as Re-Os, to acquire good age constraints. More recently, trace elements in sedimentary pyrite associated with black shales have been used to understand the paleo atmosphere-ocean redox conditions, as pyrite is an excellent host for most redox sensitive trace elements [16-21]. Apart from trace element concentrations, sedimentary pyrite textures provide insights into depositional conditions and paleo-biological conditions, i.e., when pyritized microbial textures are present.

The present study focusses on a particular part of the Upper Vindhyan stratigraphy i.e., organic matter-rich pyritic black shales, known as the Bijaigarh Shale (Kaimur Group), as exposed near Amjhore (Figure 1). The Bijaigarh Shale is an excellent repository of a variety of sedimentary pyrite textures, some of which have been described in earlier literature [22,23] being recorded here for the first time. Here we use these pyrite textures and their associated trace element and sulphur isotope concentrations to reveal ocean and atmosphere redox conditions in the Vindhyan Basin during the deposition of the Bijaigarh Shale. Recent Re-Os geochronology of the Bijaigarh Shale (1210 $\pm 52 \mathrm{Ma}$ ) by [24] allows us to further interpret our data in terms of Mesoproterozoic global paleoredox conditions.

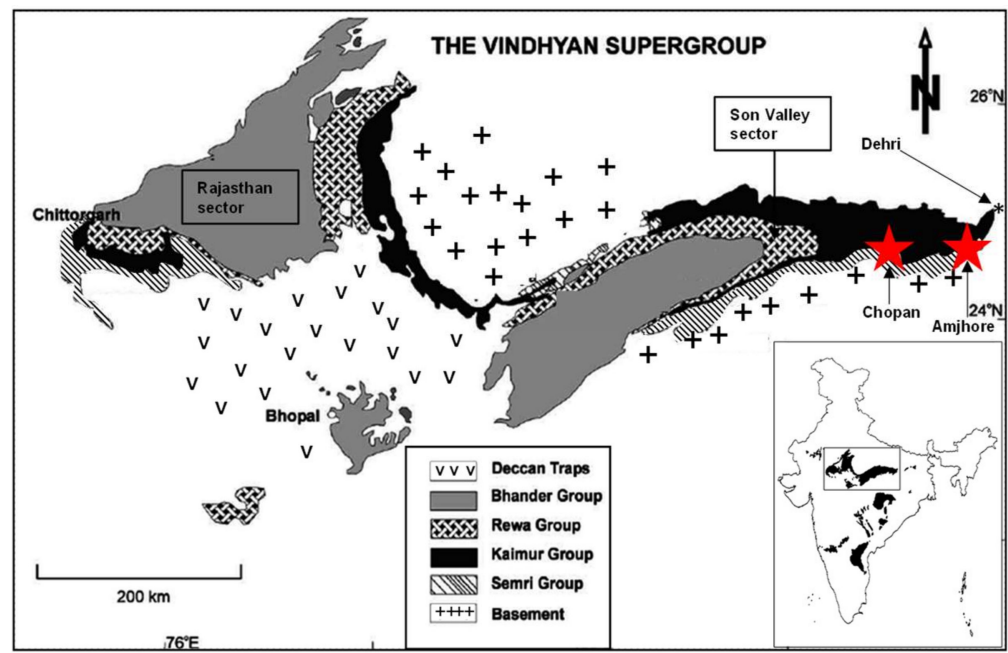

Figure 1. Geological sketch map of the Vindhyan Basin modified after [25] showing the two main sectors: Rajasthan in the west and Son valley in the east. The inset shows the different Proterozoic basins in India and the location of the Vindhyan basin in the northern cratonic block.

\section{Geological Background}

The Vindhyan Basin, like other "Purana" basins in India, is generally considered to have developed as a failed rift basin in Archean to early Paleoproterozoic basement rocks [26]. Tholeiitic magmatism around $1800 \mathrm{Ma}$ in Bijawar, Sonrai and Gwalior areas, encircling the Vindhyan Basin, bear evidence of the extensional growth of the initial rifts. Most workers now agree that the Vindhyan sediments were deposited in a westward-opening epicontinental basin in an intracratonic setting [27,28]. 


\subsection{Stratigraphy and Age}

Stratigraphically, the Vindhyan Basin is divided into the Paleoproterozoic Lower Vindhyan and the mostly Mesoproterozoic Upper Vindhyan (Figure 2), separated from each other by a basin-wide unconformity [25]. The Lower Vindhyan is represented by the Semri Group of rocks which unconformably overlie either the $1854 \pm 7$ Ma Hindoli Group of rocks [29] of the Aravalli belt or the $2492 \pm 10$ Ma Bundelkhand granites [30]. The Semri Group comprises an alternating sequence of shales, carbonates, and patchy sandstones along with two known periods of volcanic activity, with the Porcellanite Formation being the most conspicuous. The Upper Vindhyan constitutes the Kaimur, Rewa, and Bhander Groups with sandstones, shales, and marls, and volcanic activity recorded at the base of the Rewa Group. Rocks of the Kaimur Group are also intruded by diamond-bearing kimberlites and lamproites.

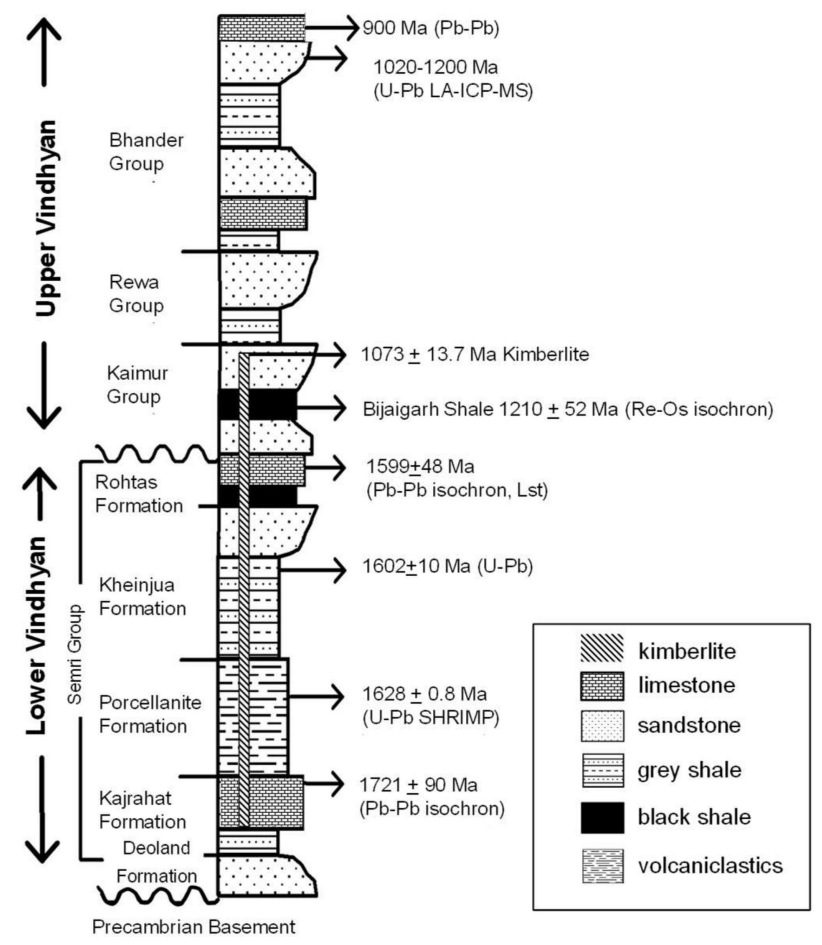

Figure 2. A generalised stratigraphic column of the Vindhyan Supergroup showing the major geochronologic data and the position of the Bijaigarh shale in the Upper Vindhyan sequence modified after [7].

The depositional age of the Vindhyan sequence has received a lot of world attention in recent years. The Lower Vindhyan sediments are now well constrained to the Paleoproterozoic between 1800-1600 Ma through a number of radiometric studies (Figure 2) on the Kajrahat Limestone [31]; Porcellanite Fm. [2]; Rampur Shale [32]; and Rohtas Limestone [33,34], mostly based on the U-Pb and $\mathrm{Pb}-\mathrm{Pb}$ dating techniques. In contrast, sediments from the Upper Vindhyan (Kaimur, Rewa and Bhander groups) still lack robust chronological control [35]. In the Son valley, a basin wide unconformity exists between the Rohtas Limestone of the Lower Vindhyan and the overlying Upper Vindhyan's, Kaimur Group, which is represented by a lower shale unit and an upper quartz-rich sandstone including a volcaniclastic deposit [36]. Amongst the three groups, the Kaimur Group is best constrained mainly due to a recent bulk rock Re-Os isochron depositional age of $1210 \pm 52 \mathrm{Ma}$ for the Bijaigarh Shale [24] in the middle part of the group. The Majhgawan kimberlite pipe, which cuts across the Semri and Kaimur groups and is exposed near Panna within upper Kaimur (Baghain) sandstones, has an emplacement age of $1073 \pm 13.7 \mathrm{Ma}$ [4]. This constrains the age of the uppermost Kaimur Group to the Mesoproterozoic and suggests that the Rewa and Bhander groups may represent 
Neoproterozoic sequences. Detrital zircon analysis of the Upper Bhander Sandstone [3] on the other hand identifies a youngest age population at 1020 Ma. Depositional age for the uppermost Bhander Group has recently been constrained by $\mathrm{Pb}-\mathrm{Pb}$ dating of three carbonate horizons by [37] at $\sim 900 \mathrm{Ma}$ (Figure 2). This short summary of geochronologic data of Vindhyan Supergroup rocks brackets its age between Late Paleoproterozoic and Early Neoproterozoic, with a substantial part of the Upper Vindhyan sequence deposited in the Mesoproterozoic.

\subsection{Bijaigarh Shale}

The Bijaigarh Shale is a laterally persistent unit of organic matter-rich black shale in the Kaimur Group, up to $70 \mathrm{~m}$ in thickness, sandwiched between the lower Kaimur Sandstone below and the upper Kaimur Sandstone above (Figure 2). The thickness of the unit decreases towards the west and the unit pinches out west of Chopan [38]. A pyritiferous horizon divides this shale unit into a lower shale (average thickness $32 \mathrm{~m}$ ) and a top shale (average thickness $15 \mathrm{~m}$ ) [39], best developed at Amjhore, about $20 \mathrm{~km}$ south of Dehri-on-Son, in the Vindhyan hills of Rohtas district, Bihar (Figure 1). Here, the pyritic shale occurs as a $0.78 \mathrm{~m}$-thick stratiform horizon within the carbonaceous shales extending over an area of $2.1 \mathrm{~km}^{2}$. The uniform thickness as well as the conformable nature of the pyrite bed with the overlying and underlying carbonaceous shale is a conspicuous feature throughout. The bottom shale has fine intercalations of sandstones and siltstones, is less carbonaceous (TOC: 1.53-1.89\%, [39]) and shows gradational contact with the lower Kaimur Sandstone. The upper shale, on the other hand, contains only a few siltstone beds, but is more carbonaceous (TOC: 3.83-4.15\%, [39]). A transitional zone of siltstone and argillaceous sandstone is reported [40] to host some galena mineralization near the upper contact of the Bijaigarh Shale with Kaimur Sandstone.

Sedimentary pyrite exhibits syn-depositional features within the carbonaceous Bijaigarh Shale [22,41,42], and attains substantial local concentration in the form of lenses and beds at Amjhore, where a pyrite mine $\left(24^{\circ} 43^{\prime} 36.9^{\prime \prime} \mathrm{N} ; 83^{\circ} 59^{\prime} 40.3^{\prime \prime}\right.$ E) was operated by Pyrites, Phosphate and Chemicals Ltd. (PPCL), a Government of India undertaking, until 2003. The top shale above the pyrite bed also has abundant pyrite disseminations and minute pyrite-rich laminae whereas the bottom shale below the orebody contains fewer disseminated pyrite. All features cumulatively suggest a deeper environment of deposition for the upper shale unit. The sediments of the Kaimur Group of rocks were deposited in a terrestrial setting, and their environment of deposition changed from alluvial fan, braided plain, fan delta to lacustrine facies [43]. The Bijaigarh Shale within the Kaimur Group is the only stratigraphic horizon to manifest a strongly anoxic environment with profuse biogenic activity, as evidenced by the prevalence of pyritiferous carbonaceous sediments. It has been considered to represent a lagoonal deposit with an open ocean connection in some studies [24,44] and inner to outer shelf by others [45]. Based on several sedimentological features, a study [46] proposed that the Bijaigarh Shale is a shelf deposit below fair-weather wave base, formed as a result of maximum flooding following a transgressive systems tract (TST), when the Vindhyan Basin was an epicratonic sea with an open ocean connection to the northwest. Presence of features like profuse gutter casts suggest intermittent storm incursions during the deposition of the Bijaigarh Shale within the overall transgressive framework [47].

\section{Methods}

The pyrite bed and the immediate bottom and top carbonaceous shales were sampled in two adjacent adits which are accessible in the erstwhile Amjhore mine. A total of nine samples were collected in vertical profiles, out of which seven samples with high to low pyrite content were studied in detail (Figure 3). The two samples rejected did not have any discernible pyrite. 


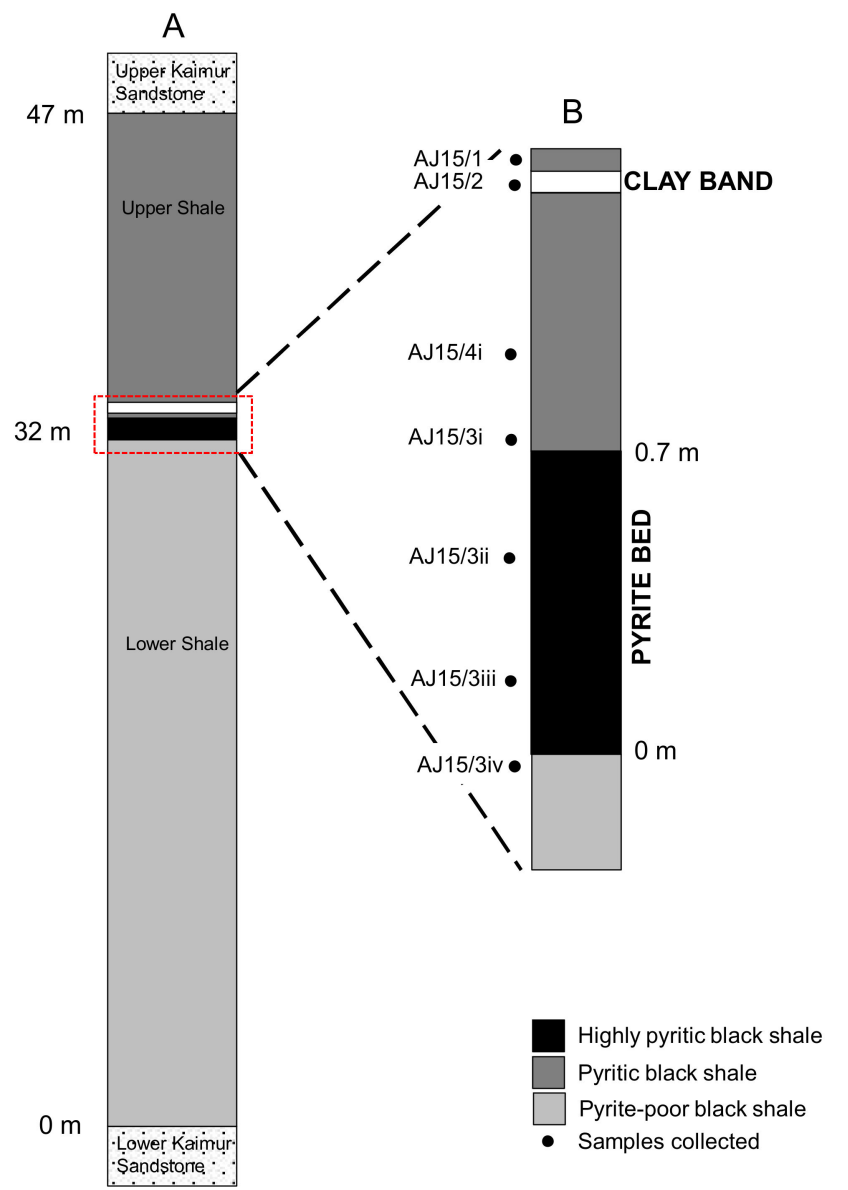

Figure 3. (A) Stratigraphic column of the Bijaigarh Shale unit at Amjhore modified after [39]; (B) Location of samples collected for this study.

\subsection{LA-ICP-MS Pyrite Analyses}

Polished 1-inch laser mounts (pieces of rock mounted in epoxy) were used for reflected light microscopy prior to trace element analyses (66 pyrite analyses) using the LA-ICP-MS facility at CODES, University of Tasmania. Analyses were performed in a time-resolved mode using ASI RESOlution Laser Ablation System comprising of CompexPro 110 ArF Excimer laser (193 nm wavelength, $20 \mathrm{~ns}$ pulse width) equipped with S155 Laurin Technic cell (Canberra, Australia) and coupled to an Agilent 7700 ICP-MS (Agilent Technologies, Santa Clara, CA, USA). Each analysis consisted of $30 \mathrm{~s}$ background and $60 \mathrm{~s}$ of ablation signal acquisition in counts per second (cps). Ablation was performed at energy density of $2.7 \mathrm{~J} / \mathrm{cm}^{2}$ and $5 \mathrm{~Hz}$ laser repetition rate, dwell times varying between 5 and $50 \mathrm{~ms}$, depending on the count rates and total sweep time (time required to measure all isotopes once) of $0.76 \mathrm{~s}$. Ablation was carried out in pure He atmosphere, introduced at a rate of $0.35 \mathrm{l} / \mathrm{min}$ in the ablation cell after which Ar was mixed with a rate of $1.05 \mathrm{l} / \mathrm{min}$ for improved efficiency of aerosol transport. Primary reference materials (STDGL2b2 glass, GSD-1G glass and pyrite crystal) were analysed every $1.5 \mathrm{~h}$ (after analyses of two samples) in order to quantify and correct for the drift in the sensitivity of the instrument. STDGL2b2 is an in-house standard used for primary calibration for quantifying siderophile and chalcophile elements [48]; GSD-1G (USGS reference material; [49] was used to quantify lithophile elements; sulfur was quantified using massive pyrite with stoichiometric Fe and S (46.5 wt.\% $\mathrm{Fe}, 53.5 \mathrm{wt} . \% \mathrm{~S}$ ). Approximately, 10 pyrite spot analyses and 5 black shale matrix spot analyses were conducted on each laser mount with $29 \mu$ spot size. Due to the fine-grained nature of the sedimentary pyrites, matrix material of the black shales was analysed for trace elements, in order to negate effects of matrix contamination during laser ablation of fine-grained pyrite. Sedimentary pyrites and matrix were analyzed for ${ }^{13} \mathrm{C},{ }^{23} \mathrm{Na},{ }^{24} \mathrm{Mg},{ }^{27} \mathrm{Al},{ }^{29} \mathrm{Si},{ }^{34} \mathrm{~S},{ }^{39} \mathrm{~K},{ }^{43} \mathrm{Ca},{ }^{49} \mathrm{Ti},{ }^{51} \mathrm{~V},{ }^{53} \mathrm{Cr},{ }^{55} \mathrm{Mn},{ }^{57} \mathrm{Fe},{ }^{59} \mathrm{Co},{ }^{60} \mathrm{Ni}$, 
${ }^{65} \mathrm{Cu},{ }^{66} \mathrm{Zn},{ }^{75} \mathrm{As},{ }^{77} \mathrm{Se},{ }^{85} \mathrm{Rb},{ }^{88} \mathrm{Sr},{ }^{90} \mathrm{Zr},{ }^{95} \mathrm{Mo},{ }^{107} \mathrm{Ag},{ }^{111} \mathrm{Cd},{ }^{118} \mathrm{Sn},{ }^{121} \mathrm{Sb},{ }^{125} \mathrm{Te},{ }^{137} \mathrm{Ba},{ }^{157} \mathrm{Gd},{ }^{178} \mathrm{Hf}$, ${ }^{181} \mathrm{Ta},{ }^{182} \mathrm{~W},{ }^{195} \mathrm{Pt},{ }^{197} \mathrm{Au},{ }^{202} \mathrm{Hg},{ }^{205} \mathrm{Tl},{ }^{206} \mathrm{~Pb},{ }^{207} \mathrm{~Pb},{ }^{208} \mathrm{~Pb},{ }^{209} \mathrm{Bi},{ }^{232} \mathrm{Th}$, and ${ }^{238} \mathrm{U}$. We report only limited range of trace elements such as $\mathrm{Co}, \mathrm{Ni}, \mathrm{Se}, \mathrm{Mo}, \mathrm{Zn}, \mathrm{Pb}, \mathrm{Tl}$ and $\mathrm{Cu}$, which are presented in Table S1. Raw LA-ICP-MS generated-data, in counts per seconds were converted into parts per million (ppm) using CODES in-house data reduction software according to [50].

\subsection{SHRIMP Sulfur Isotopes}

Sulfur isotope compositions $\left(\delta^{34} S\right.$ and $\left.\Delta^{33} S\right)$ were measured in-situ in pyrite with the SHRIMP-SI ion microprobe at the Research School of Earth Sciences, the Australian National University (ANU). The mounts were cleaned using ethanol, a dilute alkaline cleaning solution, and de-ionised water and dried in a vacuum oven at $60{ }^{\circ} \mathrm{C}$ for $24 \mathrm{~h}$, prior to analyses. Mounts were coated with ca. of $10 \mathrm{~nm}$ of $\mathrm{Au}$ before being placed into a steel holder for insertion into the SHRIMP sample lock. A Cs ${ }^{+}$ primary beam of $\sim 2 \mathrm{nA}$ was focused to sputter an area of $\sim 25 \mu \mathrm{m}$ in diameter on the Au-coated target surface. Faraday cups were used for simultaneous detection of ${ }^{32} S^{-},{ }^{33} S^{-}$and ${ }^{34} S^{-}$. Signals of ${ }^{32} \mathrm{~S}^{-}$were collected on a $10^{11} \Omega$ resistor $\left(50 \mathrm{~V}\right.$ range), ${ }^{33} \mathrm{~S}^{-}$and ${ }^{34} \mathrm{~S}^{-}$on $10^{11} \Omega$ resistors $(5 \mathrm{~V}$ range). Under the operation conditions described, typical count rates on ${ }^{32} \mathrm{~S}^{-}$were $\sim 0.2-1.2 \times 10^{9} \mathrm{cps}$, on ${ }^{33} \mathrm{~S}^{-}$ about $1.2-9.2 \times 10^{6} \mathrm{cps}$, and on ${ }^{34} \mathrm{~S}^{-}$about $0.7-5.2 \times 10^{7} \mathrm{cps}$. Additional specifications on analytical conditions of the analyses are described in [51,52]. Data were collected in 1 or 2 sets (6-10 subsets), $20 \mathrm{~s}$ each, with each subset comprising ten $2 \mathrm{~s}$ integrations.

Unknown pyrite analyses were bracketed by measurements of pyrite reference material Balmat $\left(\delta^{34} \mathrm{~S}=+15.1 \pm 0.2 \%\right.$, [53,54]. The measured ${ }^{33} \mathrm{~S} /{ }^{32} \mathrm{~S}$ and ${ }^{34} \mathrm{~S} /{ }^{32} \mathrm{~S}$ ratios, were corrected for instrumental mass fractionation, and expressed here in standard delta notation in permil (\%o) relative to V-CDT (VCDT_Vienna-Canyon Diablo Troilite), with:

$$
\begin{aligned}
\delta^{33} S_{V-C D T} & =1000 \times\left[\frac{\left({ }^{33} S /{ }^{32} S\right)_{\text {corrected }}}{\left({ }^{3} S / 32 S\right)_{\text {reference }}}-1\right](\%) \\
\delta^{34} S_{V-C D T} & =1000 \times\left[\frac{\left({ }^{34} S /{ }^{32} S\right)_{\text {corrected }}}{\left({ }^{34} S / 32 S\right)_{\text {reference }}}-1\right](\%)
\end{aligned}
$$

Capital delta values $\left(\Delta^{33} S\right)$ were calculated following [53], where:

$$
\Delta^{33} S=\delta^{33} S-1000 \times\left(\left(1+\frac{\delta^{34} S}{1000}\right)^{0.515}-1\right)
$$

Internal precision of single spot analyses of $\delta^{34} S$ and $\Delta^{33} S$ were generally better than $0.1 \%$ and $0.3 \%$ ( $2 \mathrm{SE}$; SE = standard error), respectively. Repeatability of $\delta^{34} \mathrm{~S}$ and $\Delta^{33} \mathrm{~S}$ values ranged between 0.2 and $0.3 \%$. These values were calculated as the 1 sigma standard deviation (SD) of all analyses on the Balmat reference material over the course of an analytical session.

\section{Results}

\subsection{Pyrite Textures Using Reflected Light Microscopy}

A textural study of the pyrite grains using reflected light microscopy was undertaken for two reasons. First, sedimentary pyrite textures can provide clues to the depositional conditions including redox, water column stratification, energy conditions, and microbial activity, as highlighted in several previous studies [6,55-63]. Second, pyrite textures were carefully recorded prior to LA-ICP-MS analyses in order to ensure only sedimentary to early-diagenetic pyrites were analysed for the study.

The pyrite bed in Amjhore is characterised by two different varieties of pyrite: a cryptocrystalline massive type and a disseminated type. The bulk of the pyrite belongs to the former type and comprises 
pyrite spheroids and idiomorphic pyrite crystals within a groundmass of cryptocrystalline pyrite. The disseminated type is made up of dense agglomerations of framboidal pyrite and disseminated subhedral to euhedral grains of pyrite in the carbonaceous shale, with the pyrite spherules ranging in diameter from 100 to $1200 \mu \mathrm{m}$ [22,41,64]. It also comprises pyritic clasts, either dispersed or concentrated in patches and bands.

This study focused on the disseminated pyrite types and identified various sedimentary pyrite textures in the Bijaigarh Shale. Most common are the fine-grained disseminations of sedimentary pyrite grains in carbonaceous shale, including aggregates of fine-grained pyrite coalesced in sub-rounded to elongated patches parallel to the bedding plane (Figure 4a).Within such bedding foliation, sometimes wavy, framboids of pyrite are also noted (Figure $4 \mathrm{~b}$ ), which have also been described in previous studies of Amjhore pyrite [22,23,65]. In some samples, partial (Figure 4c) to complete (Figure 4d) replacement of preexisting spherical structures in the black shale matrix by pyrite is observed.

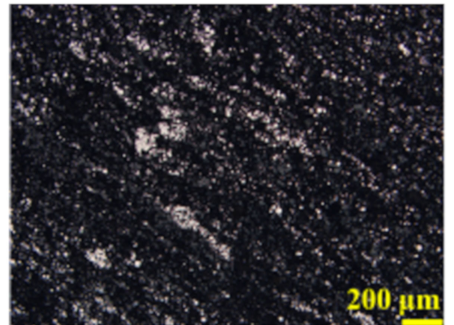

a)

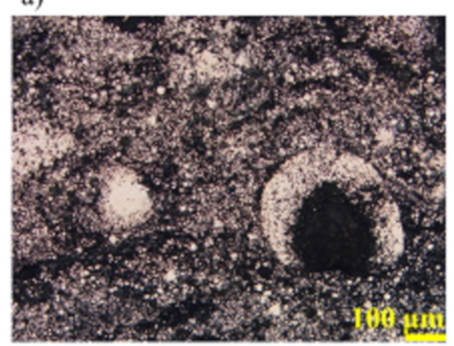

c)

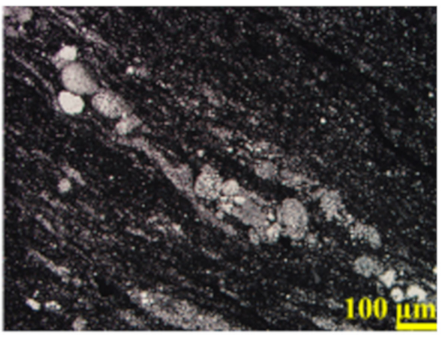

b)

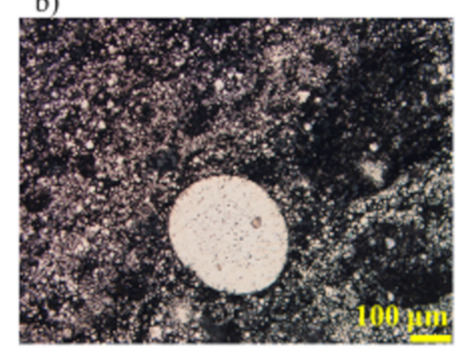

d)

Figure 4. Photomicrographs under reflected light; $(\mathbf{a}, \mathbf{b})$ : fine grained pyrite disseminated in black shale matrix; $(\mathbf{c}, \mathbf{d})$ : pyrite spheres within a pyritic black shale matrix.

Rounded-sub-rounded clasts of pyrite dispersed in a pyritic black shale matrix are interpreted as pyrite lag deposits (Figure 5a,b), formed by physical reworking of the pyrite bed in a high-energy environment. Both zoned and unzoned pyrite overgrowths are also present in such deposits (Figure 5c,d).

Some nodular/spheroidal and stromatolitic/microlaminar carbonaceous concentrations (Figure 6a,b) in the pyritic shale groundmass possibly represent microbial structures. Pyrite infillings in a possibly geopetal structure (Figure 6c) or pyrite replacing a lensoid shape (Figure 6d) are observed in some samples. Additionally, commonly noted are pyrite clasts, possibly representing bioclasts, which have been pyritised later, during, or after the deposition of the Bijaigarh Shale (Figure 7a-d).

Overall, a variety of sedimentary textures (possibly of both biotic and abiotic origins) characterize pyritic textures in the sulfidic horizon and also in the lower and upper shales. Interpretation of these textures and several possible formation mechanisms are discussed in a later section (refer textural implications). The order in which these textures are observed and occur across the pyrite bed i.e., from the top of the bottom carbonaceous shale to the pyrite bed to the upper carbonaceous shale, is interesting to note (Figure 8). As mentioned above, fine-grained pyrite in layers, aggregates (including framboidal), and fine disseminations of microcrystals of pyrite occur all through the section. Black shales underlying the basal pyrite bed are relatively pyrite-poor compared to all other samples and pyrite mainly occurs as microcrystals disseminated in the shale. Further up stratigraphy into the pyrite bed, we observe a very pyritic shale with pyrite spheres and lenses including lag deposits where 
some individual pyrite clasts are fairly well rounded (Figure 8). In these samples, we also observe spherical concretions and stromatolite-like structures (Figure 8). Closer to the contact between the pyrite bed and upper carbonaceous shale, we observe textures like pyrite infillings and lenses that are possible geopetal structures. The upper shale exhibits streaks of fine-grained pyrite in repetitive layers. Close to the clay band, we observe another pyrite lag deposit where pyritised clasts (possibly bioclasts) are plentiful (Figure 8).
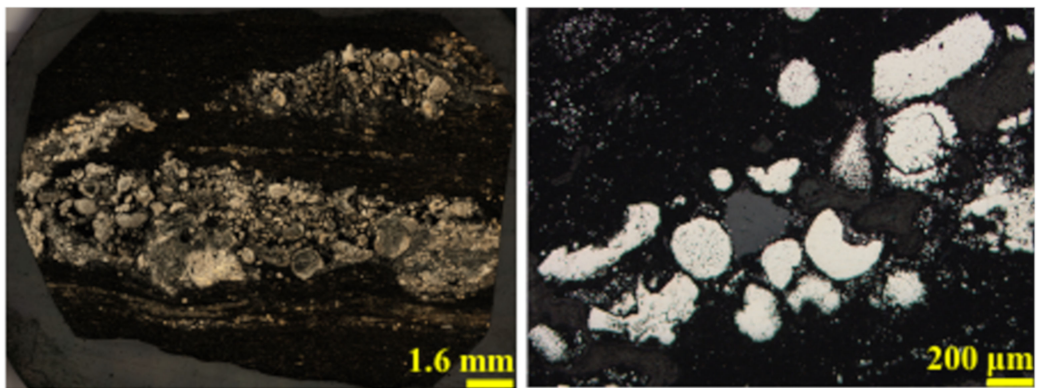

a)
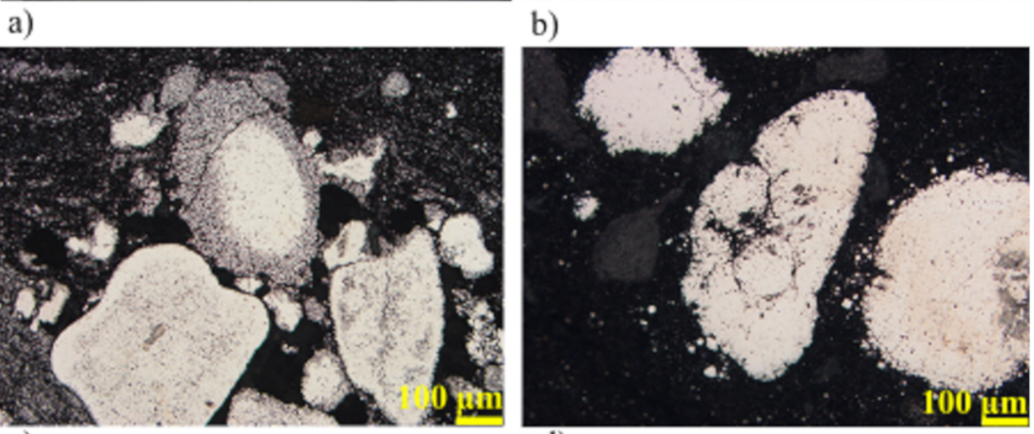

c)

d)

Figure 5. Photomicrographs under reflected light; (a) pyrite lag layer in a laser mount; (b-d) pyritic clasts within the lag layer.
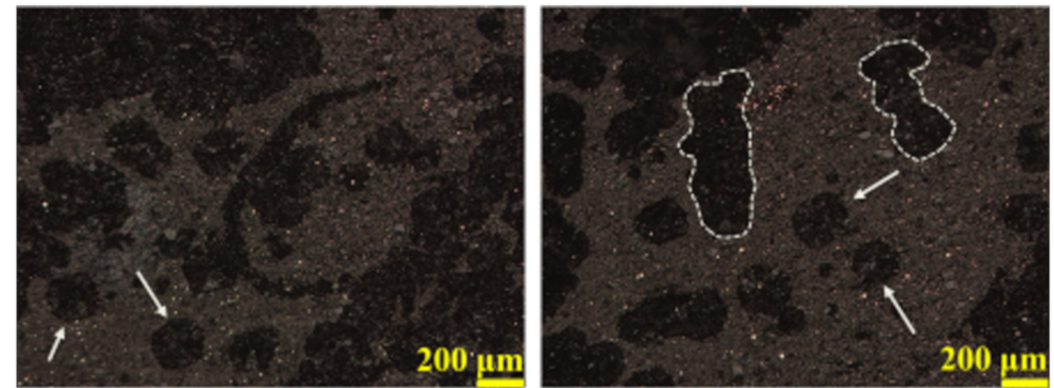

a)

b)
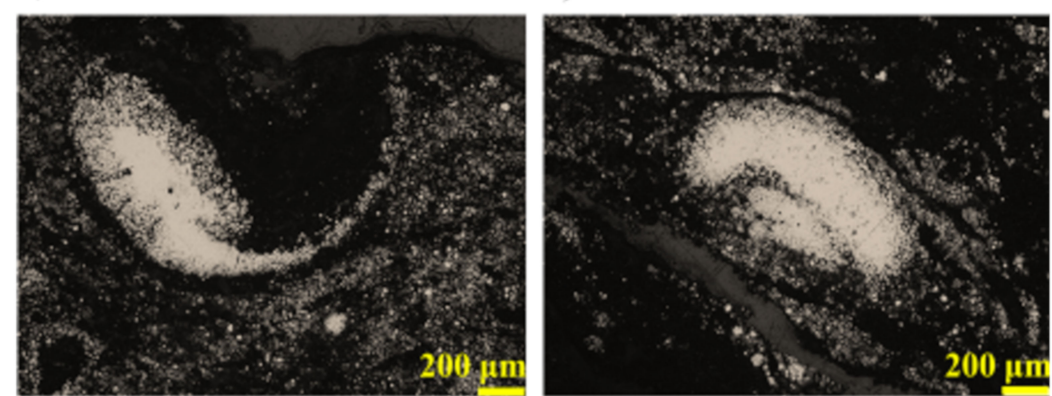

c)

d)

Figure 6. Photomicrographs under reflected light; (a,b) microbial structures (lenticular, spherical, and stromatolitic); (c) pyrite infilling structures; (d) lensoidal pyrite grain. 


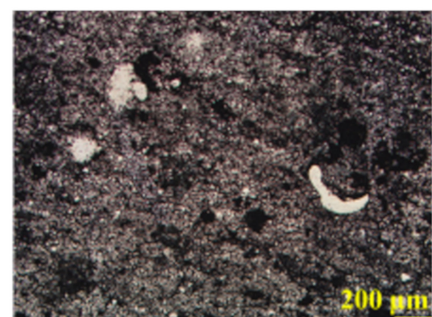

a)

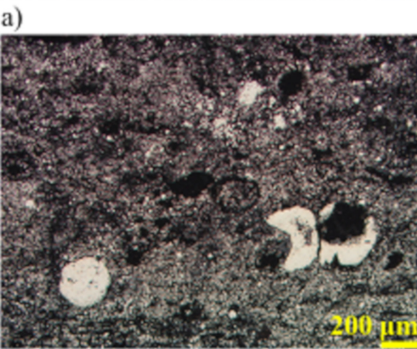

c)

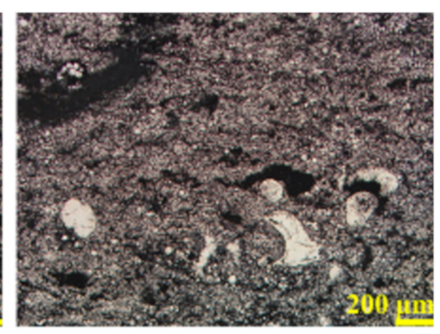

b)

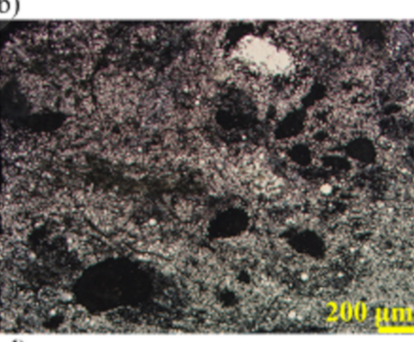

Figure 7. Photomicrographs under reflected light; (a-d) pyritic bioclasts (?).

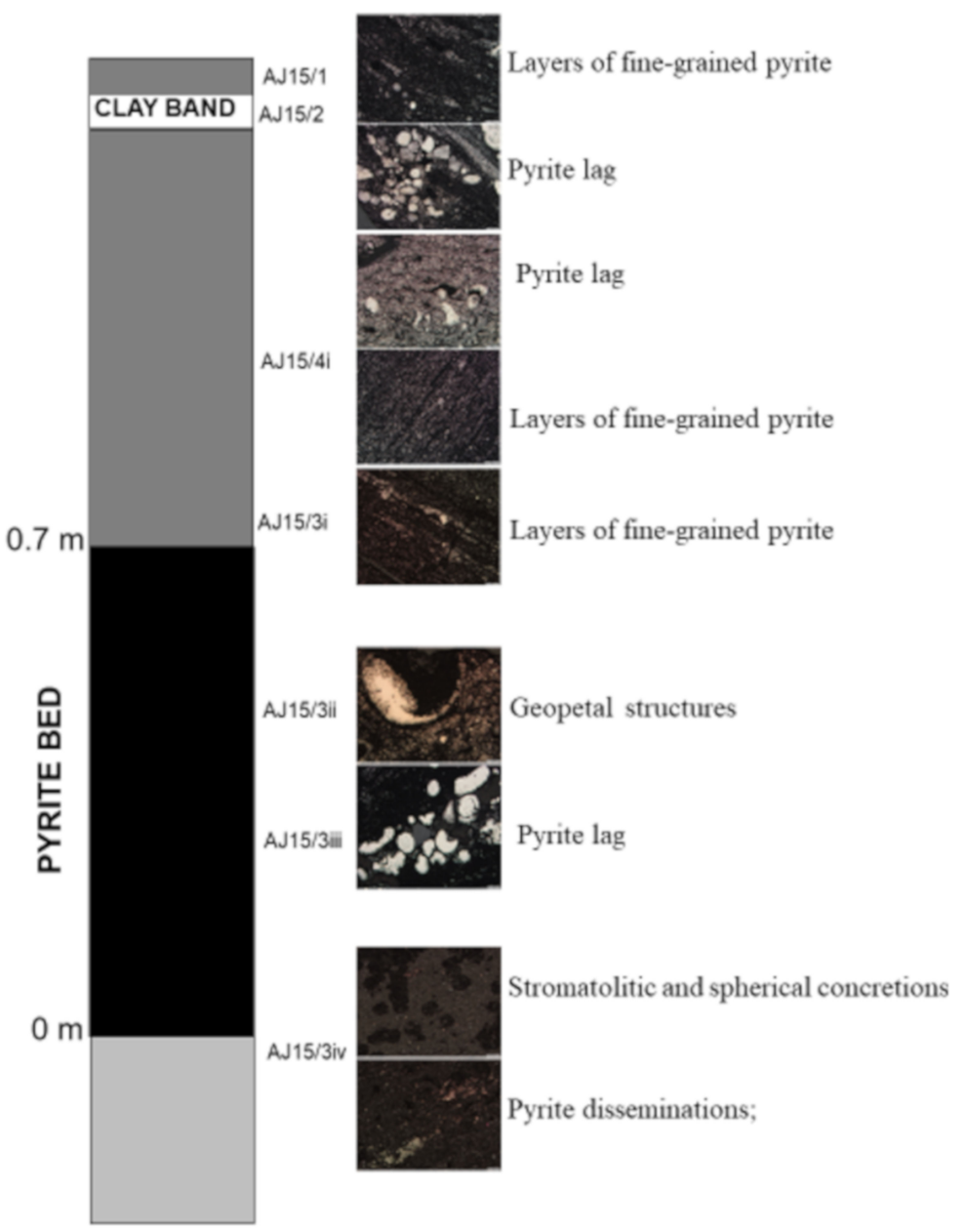

Figure 8. Textural variation observed up-stratigraphy.

\subsection{Pyrite Trace Element Chemistry}

Redox sensitive trace elements in black shales $[11,13,65]$ and more recently, in sedimentary pyrites $[16,20]$, have been used to interpret paleoredox conditions in the ocean and atmosphere. In this study, we measured key trace elements $(\mathrm{Ni}, \mathrm{Co}, \mathrm{Cu}, \mathrm{Se}, \mathrm{Mo}, \mathrm{Zn}, \mathrm{Pb}, \mathrm{Tl})$ in sedimentary pyrite 
using LA-ICP-MS to provide additional insights into the evolving depositional conditions during the formation of the Bijaigarh Shale. Pyrite trace element analyses for fine grained disseminated pyrite and the coarse pyrite lags are presented separately in Tables S1 and S2.

The fine-grained variety of pyrite in the Bijaigarh Shale unit exhibits slightly higher concentrations of $\mathrm{Ni}, \mathrm{Cu}, \mathrm{Mo}$, and high concentrations of $\mathrm{Zn}$ compared with their coarser counterparts (Table S2). $\mathrm{Mean} \mathrm{Ni}, \mathrm{Cu}$, and $\mathrm{Mo}$ in fine grained pyrite are $288 \mathrm{ppm}, 155 \mathrm{ppm}$, and $57 \mathrm{ppm}$, respectively, compared to mean values of $134 \mathrm{ppm}, 82 \mathrm{ppm}$, and $30 \mathrm{ppm}$, respectively, in coarser varieties. Mean $\mathrm{Zn}$ is $\sim 100 \mathrm{ppm}$ in finer grained pyrites compared to $35 \mathrm{ppm}$ in coarser varieties. Selenium, Co and $\mathrm{Tl}$ remain roughly the same in both varieties (Table S2); mean Se, Co and $\mathrm{Tl}$ in fine grained pyrite are $15 \mathrm{ppm}$, $340 \mathrm{ppm}$ and 16 respectively, and in coarser grains are $11 \mathrm{ppm}, 289 \mathrm{ppm}$ and $10 \mathrm{ppm}$ respectively. Very high $\mathrm{Pb}$ concentrations are noted in the coarse pyrite lags ( $1300 \mathrm{ppm})$ compared to the finer grained variety ( $\sim 200 \mathrm{ppm}$ ) (Table S2). Ratios of Se/Co, Ni/Co, Mo/Co, Zn/Co are also $\sim 2-3$ times higher in finer grained pyrites compared to coarser varieties (Table S2).

Mean of trace element concentrations of both pyrite types and their ratios in this study have been compared with the mean of $\sim 4700$ sedimentary pyrite analyses categorized into different time spans i.e., Phanerozoic, Proterozoic, and Archean $[16,18,19]$ (Table S3). This was mainly done to compare the pyrites from the Bijaigarh Shale with sedimentary pyrites of varying ages (Table S3). Mean concentrations of trace elements and their ratios in the Bijaigarh Shale unit are significantly lower than the Phanerozoic sedimentary pyrites $[16,18]$ except Co and $\mathrm{Tl}$ which are only slightly lower. Concentration of $\mathrm{Pb}$ however, is higher in the Bijaigarh pyrites relative to the Phanerozoic. When compared to the Proterozoic average, trace element concentrations and their ratios are also lower in the Bijaigarh pyrites. Cobalt, Ni, Cu concentrations, Ni/Co, $\mathrm{Zn} / \mathrm{Co}$ in the Bijaigarh Shale unit are also significantly lower compared to the Archean, with $\mathrm{Zn}$, Se, Se/Co being only slightly lower. Molybdenum, $\mathrm{Tl}, \mathrm{Pb}$, and $\mathrm{Mo} / \mathrm{Co}$ are slightly higher in the Bijaigarh Shale unit compared to the Archean.

\subsection{Sulfur Isotopes (SHRIMP_SI)}

Three samples from different stratigraphic levels of the Bijaigarh Shale Unit (AJ15/3iii: lower; AJ/4i: middle; AJ15/1: upper) were selected for sulfur isotope measurements. Pyrite sulfur isotope compositions compliment trace element chemistry as they provide additional evidence for depositional redox conditions. A total of 45 analyses were undertaken in the three samples (Table S4).

The $\delta^{34} S_{\text {VCDT }}$ values in three samples were as follows:

- $\quad$ AJ15/3iii (lower) ranged between +5.9 and $+9.7 \%$ o $(n=18)$

- $\quad$ AJ15/4i (middle) ranged between +6.23 and $11.05 \%$ o $(n=8)$

- $\quad$ AJ15/1 (upper) ranged between +6.5 and $26.08 \%$ o $(n=19)$

The $\delta^{34} \mathrm{~S}_{\mathrm{VCDT}}$ values (mean) increases from $7.8 \pm 1.06 \%$ o $1 \mathrm{SD}$ (lower) to $9.25 \pm 1.65 \%$ o $1 \mathrm{SD}$ (middle) to $12.02 \pm 3.84 \%$ o $1 \mathrm{SD}$ (upper) as we move up stratigraphy in the Bijaigarh Shale unit. The $\Delta^{33} \mathrm{~S}$ values of pyrites in the three samples are generally low, i.e., $0.14 \pm 0.21 \%$ o ( $1 \mathrm{SD}), 0.17 \pm 0.13 \%$ o (1 SD) and $0.03 \pm 0.10 \%$ o (1SD), for AJ15/3iii, AJ15/4i and AJ15/1, respectively.

\section{Discussion}

\subsection{Textural Implications}

The Bijaigarh Shale, particularly the pyrite bed and the upper carbonaceous shale, exhibits a variety of textures possibly recording the various depositional conditions operative during its formation. Sedimentation commenced in an oxygen-poor environment, created as a result of decomposition of high levels of organic matter. Assuming an authigenic supply of Fe (from the sediments or water column), bacterial sulphate reduction in the sediment/water column led to the formation of microcrystals of pyrite as evidenced by the pyrite disseminations in the lower carbonaceous shale. With subsequent 
deposition of abundant organic matter, oxygen was entirely consumed; further bacterial sulphate reduction combined with a steady supply of $\mathrm{Fe}$, the shale became more pyritic. This is indicated by the formation of pyrite in layers and aggregates grading into massive pyrite layers, i.e., the pyrite bed.

Occasional reworking of the sediments possibly caused the formation of the pyrite lags. This could be attributed to high-energy storm incursions during sedimentation. Other sedimentological studies in the formation (tidal bundles, gutter casts, etc.) also confirm such disruptive events [7,36,47]. When such high-energy events were absent, pyrite formed in layers and aggregates as commonly observed in all the samples. One could argue that the pyrite clasts in the lag deposit were derived from a distant source and not the Bijaigarh Shale. However, if that was the case, then we would expect significant differences in pyrite trace element concentrations in samples (e.g., $\mathrm{AJ} / 15 / 1$ ) where both fine-grained and pyrite lag were analysed (Tables S1 and S2). The data does not support this situation and we interpret the lags to be derived as a result of reworking of the underlying pyrite laminations.

Textural evidence suggests that some clasts within the pyrite lags may be biogenic (Figure 7). It is possible that pyrite precipitation occurred on surfaces of microbial remnants (hard or soft parts?), manifested in the form of pyritised bioclasts and pyrite infillings. A biogenic origin of these clasts is highly likely, supported by two features: high TOC\% (3-4\%) observed in the Bijaigarh Shale unit [39] and the characteristic shapes of these clasts. It is also possible that the spherical clasts are abiogenic and have formed due to extensive reworking. It is interesting to note that these spherical/rounded clasts co-occur with non-spherical clasts. Therefore, extensive reworking could not have caused sphericity/roundness in selective clasts only. Also, phosphatic concretions and microbial mat formation has been described from the Bijaigarh shale in previous studies $[23,66]$. Concretions and stromatolite-like structures have been noted in Figure 6a,b as well, which points towards a biogenic origin for these clasts.

The textural study investigated if pyrite texture types may explain their trace element content. Trace elements may be adsorbed into the structure of pyrite (chemiabsorbed onto the defect sites of Fe and $S$ on the pyrite surface) or may be incorporated as inclusions within pyrite [64]. A number of chemical factors may control trace element uptake by pyrite along with both thermodynamic as well as kinetic influences [67]. These chemical factors include electronic configuration of an element, oxidation state, ligand field stabilization energies, water exchange rates and reactivity to chemical species (hydroxide/chloride/sulphide) relative to Fe [67]. For instance, elements like $\mathrm{Zn}, \mathrm{Cd}, \mathrm{Pb}$ have higher water exchange rates relative to $\mathrm{Fe}$, due to weak to no ligand field stabilization energy (owing to electronic configuration). Higher water exchanges rates of $\mathrm{Zn}, \mathrm{Cd}$ and $\mathrm{Pb}$ facilitates their sulphide formation. These elements occur as sulphide inclusions within pyrite [67]. On the other hand, elements like $\mathrm{Ni}$ and $\mathrm{Co}$ have slow water exchange rates compared to $\mathrm{Fe}$, which precludes their sulphide formation and are adsorbed into the structure of the pyrite [67]. It should be noted that regardless of the mechanism of incorporation, trace element availability in the water column is an important prerequisite. Syngenetic pyrite trace element content may be a good measure of the trace element availability. However, subsequent transformation of syngenetic pyrite may alter the original trace element content. We speculated if pyrite morphologies may explain differences in trace element concentrations and their ratios observed in fine-grained pyrite vs pyrite lag textures. Most trace elements except $\mathrm{Pb}$ are enriched in the finer grained variety of pyrite relative to the coarser variety. Minor recrystallization of the coarse pyrite during diagenesis and lag formation may be the cause, as noted in other black shale formations [16]. However, in one sample (AJ15/1) where both types of pyrites were analysed, little differences were observed. This is why we conclude here that the variation is possibly due to changes in depositional conditions upstratigraphy. A note of caution on this conclusion as it is based on just one sample and may be speculated in future studies.

\subsection{Atmospheric Redox Implications (Pyrite-Trace Elements)}

Trace element concentrations, such as $\mathrm{Mo}, \mathrm{Se}, \mathrm{Co}, \mathrm{Zn}, \mathrm{Ni}, \mathrm{Cu}, \mathrm{Pb}, \mathrm{Tl}$ and certain trace element ratios $(\mathrm{Se} / \mathrm{Co}, \mathrm{Mo} / \mathrm{Co}, \mathrm{Zn} / \mathrm{Co}$ ) are used here to interpret paleo-atmospheric redox condition during the deposition of the Bijaigarh Shale. This is based on the fact that oxidative weathering on land 
releases these trace elements into the riverine flux, which is a dominant source of these trace elements in the marine system $[13,15,16,68-72]$. However, Co relative to Se, Mo, Ni, $\mathrm{Zn}$ is retained by Fe-Mn oxides and hydroxides on land, which decreases its supply in the riverine flux during oxygenation. Whilst $\mathrm{Mo}, \mathrm{Se}, \mathrm{Ni}$, and $\mathrm{Zn}$ should increase in concentrations in sedimentary pyrite due to progressive oxygenation on land, Co generally shows an opposite trend [20]. Any increase in the former should be accompanied by decrease in $\mathrm{Co}$; therefore, ratios of $\mathrm{Se} / \mathrm{Co}, \mathrm{Mo} / \mathrm{Co}$, and $\mathrm{Zn} / \mathrm{Co}$ are considered as robust paleo-indicators of atmospheric oxygenation. Apart from oxidative weathering, provenance of the sediments also bears a control on the type of trace element flux. Trace element patterns in this study will be discussed in light of these two trace element source parameters.

Most trace element concentrations and their ratios are below or close to the mean values for the Proterozoic, indicated in Figures 9-11 by the dashed line, which is not uncommon for Proterozoic black shales. Several studies have indicated that low atmospheric oxygen during the Proterozoic has resulted in suppressed trace element signatures in black shales $[7,13,15,16]$. Elements like Ni, Se, $\mathrm{Mo}, \mathrm{Cu}, \mathrm{Tl}$, and $\mathrm{Zn}$ show a trend where concentrations are mostly below or close to the Proterozoic mean values (dashed line in Figures 9 and 10) with Co content mostly above the Proterozoic mean value. Lead on the other hand shows a significant enrichment in the clay band present in the upper carbonaceous shale. Reasons as to why the pyrites are enriched in $\mathrm{Pb}$ are speculative. There is however a thin band of galena mineralization $(0.4 \% \mathrm{~Pb})$ in the siltstone between the upper carbonaceous shale and the Upper Sandstone. Concentrations of $\mathrm{Pb}$ other than in the clay band are generally consistent and low (below the Proterozoic mean values). Ratios of ${ }^{207} \mathrm{~Pb}$ and ${ }^{206} \mathrm{~Pb}$ of the fine-grained pyrites and $\mathrm{Pb}$-enriched pyrites were calculated and they were similar $(=0.860)$. That rules out the possibility of a later $\mathrm{Pb}$ enrichment in the sediments.
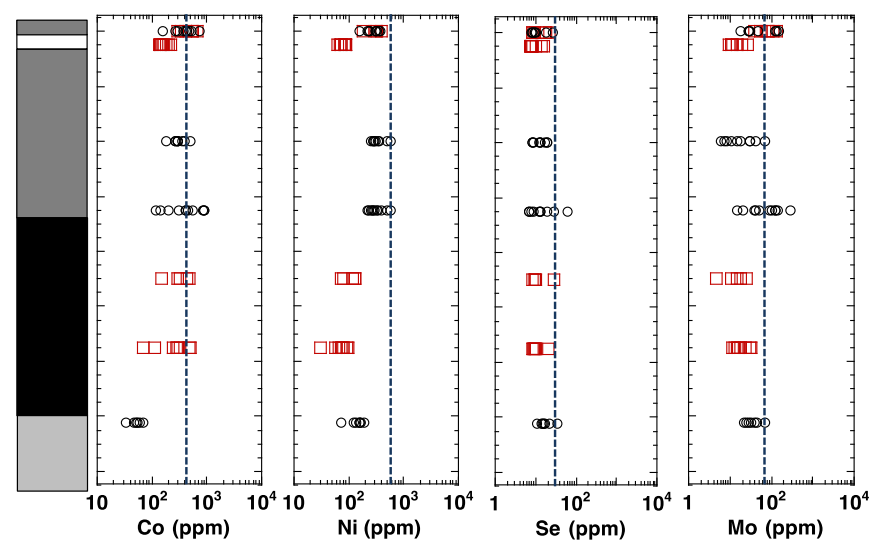

Figure 9. Trace element concentrations (Co, Ni, Se, Mo) in the Bijaigarh Black Shale Member; dashed line represents Proterozoic mean values [19]; red squares—pyrite lag; black circles—fine-grained pyrite.
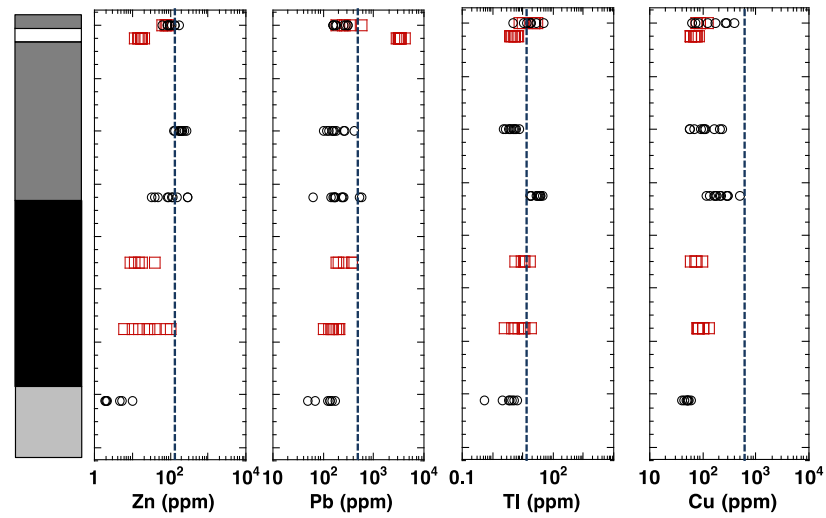

Figure 10. Trace element concentrations $(\mathrm{Zn}, \mathrm{Pb}, \mathrm{Tl}, \mathrm{Cu})$ in the Bijaigarh Black Shale Member; dashed line represents Proterozoic mean values [19]; red squares-pyrite lag; black circles-fine-grained pyrite. 


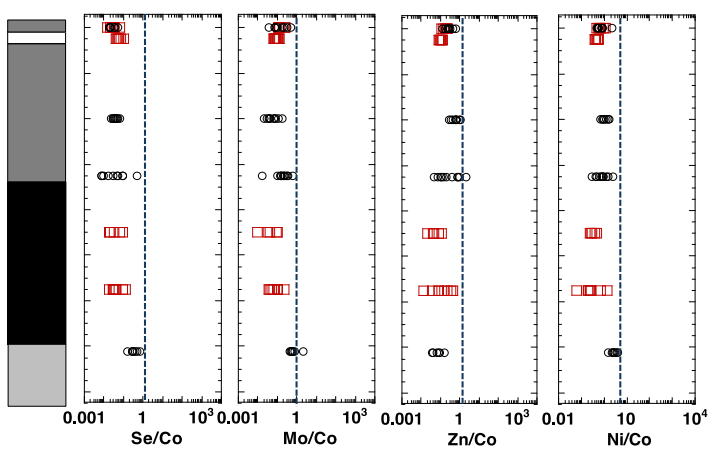

Figure 11. Trace element ratios (Se/Co, $\mathrm{Mo} / \mathrm{Co}, \mathrm{Ni} / \mathrm{Co}, \mathrm{Zn} / \mathrm{Co}$ ) in the Bijaigarh Shale Member; dashed line represents Proterozoic mean values [19]; red squares—pyrite lag; black circles-fine-grained pyrite.

Other oxygenation proxies such as $\mathrm{Se} / \mathrm{Co}, \mathrm{Mo} / \mathrm{Co}$, and $\mathrm{Zn} / \mathrm{Co}$ are all below the Proterozoic mean value (Figure 11) indicating an absence of any significant oxygenation. Ratios of Se/Co and Mo/Co of the Bijaigarh Shale unit have also been compared to Archean and Phanerozoic (Figure 12). It is evident that although values are significantly lower than the Phanerozoic, they are higher than the Archean. This implies lower atmospheric oxygen levels at $\sim 1.2$ Ga relative to the Phanerozoic but higher than the Archean (Figure 12). Ratios were also compared with pyrites from Neo-Meso-Paleoproterozoic to demonstrate that the data fits in well with the average Proterozoic analyses (Figure 13).

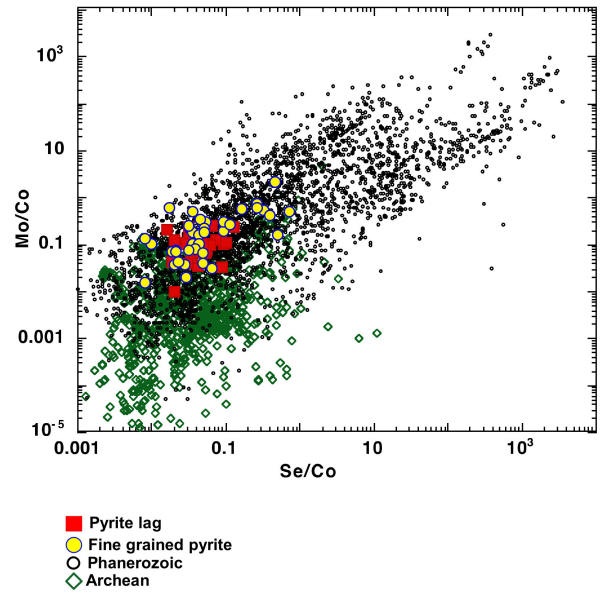

Figure 12. Comparison of Se/Co vs Mo/Co in the Bijaigarh Black Shale unit with Archean and Phanerozoic sedimentary pyrites [16,18].

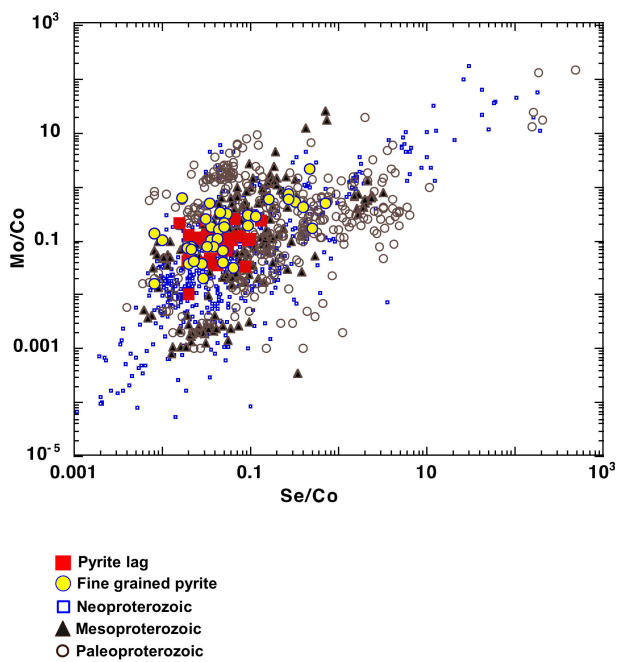

Figure 13. Comparison of Se/Co vs Mo/Co in the Bijaigarh Black Shale unit with Proterozoic pyrites [19]. 


\subsection{Atmospheric Redox Implications (Pyrite-Sulfur Isotopes)}

In order to have further insights into the redox state of the depositional conditions of the Bijaigarh shales, sulfur isotope compositions of three samples were studied. An increase in $\delta^{34} S_{\text {pyrite }}$ values up stratigraphy in the Bijaigarh Shale was observed, which could be interpreted in several ways (Figure 14). First, it may represent a transition from a partially closed to a closed system depositional conditions, with progressively heavier values as we move up stratigraphy. That is because progressive cessation of open ocean connection would hinder fresh injections of sulphate for reduction. This will result in the seawater being more enriched in ${ }^{34} \mathrm{~S}$ after ${ }^{32} \mathrm{~S}$ has been exhausted. Following that, the pyrites will progressively incorporate the heavier isotope. Alternatively, an overall decrease in $p \mathrm{O}_{2}$ of the atmosphere-ocean system as discussed above, would also impede the supply of the sulphate in the oceans and therefore causing the pyrites to incorporate the heavier isotope $\left({ }^{34} \mathrm{~S}\right)$ due Rayleigh fractionation. Important to note here is the absence of negative $\delta^{34} S_{\text {pyrite }}$ values, which may also imply lower seawater sulphate that may have been bacterially reduced to pyrite with heavier values. Our data is also consistent with observations made by [7,41], where a combination of closed system, anoxic ocean conditions, and lower marine sulphate concentrations (owing to lower oxidative weathering) were proposed for the Bijaigarh Shale.

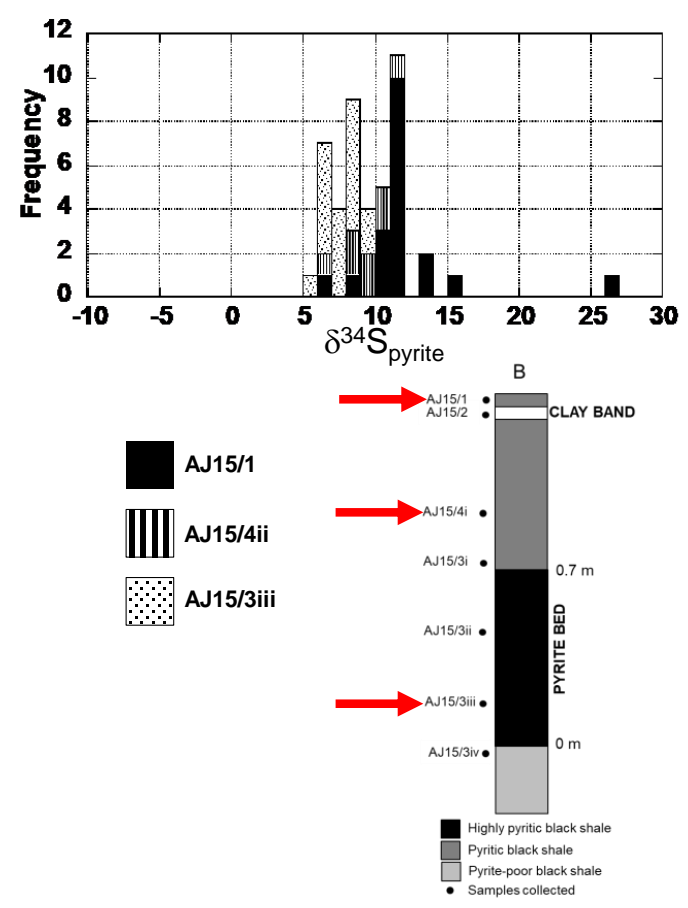

Figure 14. SHRIMP-SI Pyrite Sulfur isotope composition in the Bijaigarh Shale Unit.

\subsection{Summary}

Pyrite trace element concentrations and their ratios in the Bijaigarh Shale are well below the global Proterozoic mean values (except $\mathrm{Pb}$ enrichment in the clay band). Sulphur isotope ratios of pyrite $\left(\delta^{34} S_{\text {pyrite }}\right)$ exhibit an increase in upstratigraphy. The combination of the pyrite trace element and sulphur isotope characteristics in the Bijaigarh Shale suggest a few possibilities. First, lack of sufficient oxidative weathering on land led to a decreased supply of trace elements and sulphate in the marine system via riverine flux rendering the trace element values in pyrite to be lower than or similar to the Proterozoic mean values and heavier $\delta^{34} S_{\text {pyrite }}$ values, respectively. Although, it should be noted that a recent study by [19] indicated $~ 7-8 \%$ PAL (Present Atmospheric Level) of $\mathrm{O}_{2}$ wt. $\%$ during the Mesoproterozoic, i.e., 0.38 PAL, much higher than 0.002 PAL suggested by [72]. Therefore, the decrease in oxygenation referred in this study is relative to the time prior to the deposition of Bijaigarh Shale. It is possible that provenance played a role in controlling the trace element patterns in the Bijaigarh 
Shale. A dominantly felsic provenance (post-Archean Proterozoic in age), is proposed for the Upper Kaimur Group on the basis of various geochemical discriminants, elemental ratios, like $\mathrm{K}_{2} \mathrm{O} / \mathrm{Na}_{2} \mathrm{O}$, $\mathrm{Al}_{2} \mathrm{O}_{3} / \mathrm{TiO}_{2}, \mathrm{SiO}_{2} / \mathrm{MgO}, \mathrm{La} / \mathrm{Sc}, \mathrm{Th} / \mathrm{Sc}, \mathrm{Th} / \mathrm{Cr}, \mathrm{Gd}_{\mathrm{N}} / \mathrm{Yb}_{\mathrm{N}}$ and pronounced negative Eu anomalies [73]. The felsic provenance for the Kaimur Group (including the Bijaigarh Shale) combined with relatively low oxidative weathering may have caused the low trace element concentration in pyrites as observed in this study. That is because most redox sensitive and nutrient trace elements (Ni, Co, Mn, Cu, Zn, $\mathrm{Se}, \mathrm{V}$ ) are relatively enriched in mafic rocks compared to felsic rocks [74]. Elements like Mo and $\mathrm{Tl}$ however, are slightly more enriched in felsic compared to mafics [74].

\section{Conclusions}

This study involved understanding sedimentary pyrite textures, their trace element and sulphur isotope ratios to reflect on paleo-redox conditions during the deposition of the Bijaigarh Shale unit in the Mesoproterozoic. Sedimentary pyrite textures indicate variable depositional conditions for the Bijaigarh Shale. Deposition began with fine-grained pyrite disseminations in layers and aggregates, suggesting a quiet, low energy environment and mildly reducing water column conditions. With subsequent enhancement of organic matter deposition and its decomposition, the water column gradually became more strongly reducing and potentially, a closed system, resulting in the formation of the pyrite bed. Occasional reworking of the pyrite bed during storm incursions caused the pyrite lags to form. Overall, low concentrations of the trace elements particularly Se and Mo and their ratios (i.e., below the global mean values for the Proterozoic) suggest relatively low oxygen conditions during the deposition of the Bijaigarh Shale. Decreasing oxygenation and closure of open ocean connection during deposition of the unit, potentially caused a lower input of sulfate in the ocean resulting in ${ }^{34}$ Srich-seawater and

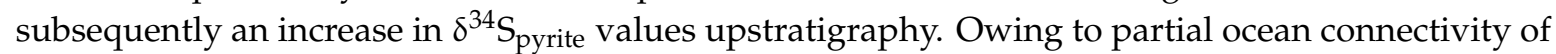
the Vindhyan Basin during the deposition of the lower part of the Bijaigarh Shale (1210 $\pm 52 \mathrm{Ma})$, there remains a possibility of extrapolating these paleoredox conditions for a more global context in the Mesoproterozoic.

Supplementary Materials: The following are available online at http://www.mdpi.com/2075-163X/10/7/588/s1, Table S1: Pyrite LA-ICP-MS analyses in Bijaigarh shales in ppm, Table S2: Mean trace element concentrations of fine-grained pyrite vs pyrite lag, Table S3: Mean trace elements in this study compared to mean pyrite analyses by [16-19]; concentrations are in ppm, Table S4: SHRIMP-SI pyrite analyses in AJ15/1, AJ/154i, AJ15/3iii in \%o.

Author Contributions: Conceptualization, I.M.; Data curation, I.M., J.Á. and I.B.; Formal analysis, I.M.; Funding acquisition, R.R.L.; Investigation, M.D.; Methodology, I.M., J.Á. and I.B.; Resources, M.D.; Writing - original draft, I.M.; Writing-review \& editing, I.M., M.D., R.R.L., J.H. and S.M. All authors have read and agreed to the published version of the manuscript.

Funding: This research was funded by Australian Research Council (ARC) project DP 150102578 awarded to RRL.

Acknowledgments: We would like to thank Mansur Ahmad for helping with the logistics during the field work at Amjhore. We also thank Cassady Harraden for her help with pyrite texture imaging.

Conflicts of Interest: The authors declare no conflict of interest.

\section{References}

1. Crawford, A.R.; Compston, W. The age of the Vindhyan system of peninsular India. Q. J. Geol. Soc. Lond. 1970, 125, 351-371. [CrossRef]

2. Ray, J.S.; Martin, M.W.; Veizer, J.; Bowring, S.A. U-Pb Zircon dating and Sr isotope systematics of the Vindhyan Supergroup, India. Geology 2002, 30, 131-134. [CrossRef]

3. Malone, S.J.; Meert, J.G.; Banerjee, D.M.; Pandit, M.K.; Tamrat, E.; Kamenov, G.D.; Pradhan, V.R.; Sohl, L.E. Paleomagnetism and detrital zircon geochronology of the Upper Vindhyan sequence, Son Valley and Rajasthan, India: A ca. 1000 Ma closure age for the Purana Basins? Precam. Res. 2008, 164, 137-159. [CrossRef] 
4. Gregory, L.C.; Meert, J.G.; Pradhan, V.; Pandit, M.K.; Tamrat, E.; Malone, S.J. A paleomagnetic and geochronologic study of the Majhgawan kimberlite, India: Implications for the age of the Vindhyan Supergroup. Precam. Res. 2006, 149, 65-75. [CrossRef]

5. Azmi, R.J.; Joshi, D.; Tewari, B.N.; Joshi, M.N.; Srivastava, S.S. A synoptic view on the current discordant geo- and biochronological ages of the Vindhyan Supergroup, central India. J. Himal. Geol. 2008, 29, 177-191.

6. Bengtson, S.; Belivanova, V.; Rassmussen, B.; Whitehouse, M.J. The Vindhyan enigma revisited. Geol. Soc. Am. Abstr. 2007, 39, 331.

7. Sarkar, A.; Chakraborty, P.P.; Mishra, B.; Bera, M.K.; Sanyal, P.; Paul, S. Mesoproterozoic sulphidic ocean, delayed oxygenation and evolution of early life: Sulfur isotope clues from Indian Proterozoic basins. Geol. Mag. 2010, 147, 206-218. [CrossRef]

8. Deb, M.; Pal, T. Mineral potential of Proterozoic intracratonic basins in India. In Precambrian Basins of India: Stratigraphic and Tectonic Context; Mazumder, R., Eriksson, P.G., Eds.; Geological Society: London, UK, 2015; Volume 43, pp. 309-325.

9. Brasier, M.D.; Lindsay, J.F. A billion years of environmental stability and the emergence of eukaryotes: New data from northern Australia. Geology 1998, 26, 555-558. [CrossRef]

10. Algeo, T.J.; Maynard, J.B. Trace element behavior and redox facies in core shales of Upper Pennsylvanian Kansas-type cyclothems. Chem. Geol. 2004, 206, 289-318. [CrossRef]

11. Algeo, T.J.; Lyons, T.W. Mo-total organic carbon covariation in modern anoxic marine environments: Implications for analysis of paleoredox and paleohydrographic conditions. Paleoceanography 2006, 21, PA1016-23. [CrossRef]

12. Algeo, T.J.; Rowe, H. Paleoceanographic applications of trace-metal concentration data. Chem. Geol. 2012, 324, 6-18.

13. Scott, C.; Lyons, T.W.; Bekker, A.; Shen, Y.; Poulton, S.W.; Chu, X.; Anbar, A.D. Tracing the stepwise oxygenation of the Proterozoic ocean. Nature 2008, 452, 456-459. [CrossRef] [PubMed]

14. Gordon, G.W.; Lyons, T.W.; Arnold, G.L.; Roe, J.; Sageman, B.B.; Anbar, A.D. When do black shales tell molybdenum isotope tales? Geology 2009, 37, 535-538. [CrossRef]

15. Sahoo, S.K.; Planavsky, N.J.; Kendall, B.; Wang, X.; Shi, X.; Scott, C.; Anbar, A.D.; Lyons, T.W.; Jiang, G. Ocean oxygenation in the wake of the Marinoan glaciation. Nature 2012, 489, 546-549. [CrossRef]

16. Large, R.R.; Halpin, J.A.; Danyushevsky, L.V.; Maslennikov, V.V.; Bull, S.W.; Long, J.A.; Gregory, D.D.; Lounejeva, E.; Lyons, T.W.; Sack, P.J.; et al. Trace element content of sedimentary pyrite as a new proxy for deep-time ocean- atmosphere evolution. Earth Planet Sci. Lett. 2014, 389, 209-220. [CrossRef]

17. Large, R.R.; Gregory, D.G.; Steadman, J.A.; Tomkins, A.G.; Lounejeva, E.; Danyushevsky, L.V.; Halpin, J.A.; Maslennikov, V.V.; Sack, P.J.; Mukherjee, I.; et al. Gold in the oceans through time. Earth Planet Sci. Lett. 2015, 428, 139-150. [CrossRef]

18. Large, R.R.; Halpin, J.A.; Lounejeva, E.; Danyushevsky, L.V.; Maslennikov, V.V.; Gregory, D.; Sack, P.J.; Haines, P.W.; Long, J.A.; Makoundi, C.; et al. Cycles of nutrient trace elements in the Phanerozoic ocean. Gond. Res. 2015, 28, 1282-1293. [CrossRef]

19. Large, R.; Mukherjee, I.; Gregory, D.; Steadman, J.; Corkrey, R.; Danyushevsky, D. Atmosphere oxygen cycling through the Proterozoic and Phanerozoic. Min. Depos. 2019, 54, 485-506. [CrossRef]

20. Mukherjee, I.; Large, R. Pyrite trace element chemistry of the Velkerri Formation, Roper Group, McArthur Basin: Evidence for atmospheric oxygenation during the Boring Billion. Precam. Res. 2016, 281, 13-26. [CrossRef]

21. Mukherjee, I.; Large, R.R. Application of Pyrite Trace Element Chemistry to Exploration for SEDEX Style Zn-Pb Deposits: McArthur Basin, Northern Territory Australia. Ore Geol. Rev. 2017, 81, 1249-1270. [CrossRef]

22. Pandalai, H.S.; Chandra, D. Textural Studies on the ores of Amjhore pyrite deposit, Rohtas district, Bihar. India. J. Geol. Soc. India 1986, 27, 527-530.

23. Sur, S.; Schieber, J.; Banerjee, S. Petrographic observations suggestive of microbial mats from Rampur shale and Bijaigarh shale, Vindhyan Basin, India. J. Earth Sys. Sci. 2006, 115, 61-66. [CrossRef]

24. Tripathy, G.R.; Singh, S.K. Re-Os depositional age for black shales from the Kaimur Group, Upper Vindhyan, India. Chem. Geol. 2015, 413, 63-72. [CrossRef]

25. Soni, M.K.; Chakraborty, S.; Jain, V.K. Vindhyan Supergroup-A review. In Purana Basins of Peninsular India (Middle to Late Proterozoic); Radhakrishna, B.P., Ed.; Geological Society: Bangalore, India, 1987; Memoir 6; pp. 87-138. 
26. Chaudhuri, A.K.; Saha, D.; Deb, G.K.; Deb, S.P.; Mukherjee, M.K.; Ghosh, G. The Purana basins of southern cratonic province of India- A case for Mesoproterozoic fossil rifts. Gond. Res. 2002, 5, 23-33. [CrossRef]

27. Chanda, S.K.; Bhattacharyya, A. Vindhyan sedimentation and paleogeography: Post-Auden developments. In Geology of Vindhyanchal; Valdiya, K.S., Bhatia, S.B., Gaur, V.K., Eds.; Hindustan Publishing Corporation: New Delhi, India, 1982; pp. 88-101.

28. Chakraborty, C.; Karmakar, S. Structural architecture of Vindhyan strata in Son valley: Implications for basin tectonics. J. Geol. Soc. India 1998, 51, 377-382.

29. Deb, M.; Thorpe, R.; Krstic, D. Hindoli Group of rocks in the Eastern Fringe of the Aravalli-Delhi Orogenic belt-Archean secondary greenstone belt or Proterozoic supracrustals? Gond. Res. 2002, 5, 879-883. [CrossRef]

30. Mondal, M.E.A.; Goswami, J.N.; Deomurari, M.P.; Sharma, K.K. Ion microprobe ${ }^{207} \mathrm{~Pb} /{ }^{206} \mathrm{~Pb}$ ages of zircons from the Bundelkhand Massif, northern India: Implications for crustal evolution of the Bundelkhand-Aravalli supercontinent. Precam. Res. 2002, 117, 85-100. [CrossRef]

31. Kumar, A.; Gopalan, K.; Rajagopalan, G. Age of the Lower Vindhyan sediments, central India. Curr. Sci. 2001, 81, 806-809.

32. Rasmussen, B.; Bose, P.K.; Sarkar, S.; Banerjee, S.; Fletcher, I.R.; McNaughton, N.J. 1.6 Ga U-Pb zircon age for the Chorhat Sandstone, lower Vindhyan, India: Possible implications for early evolution of animals. Geology 2002, 30, 103-106. [CrossRef]

33. Ray, J.S.; Veizer, J.; Davis, W.J. C, O, Sr and Pb isotope systematics of carbonate sequences of the Vindhyan Supergroup, India: Age, diagenesis, correlations and implications for global events. Precam. Res. 2003, 121, 103-140. [CrossRef]

34. Sarangi, S.; Gopalan, K.; Kumar, S. Pb-Pb age of the earliest megascopic, eukaryotic alga-bearing Rohtas Formation, Vindhyan Supergroup, India: Implications for Precambrian atmospheric oxygen evolution. Precam. Res. 2004, 121, 107-121. [CrossRef]

35. Ray, J.S. Age of the Vindhyan Supergroup: A review of recent findings. J. Earth Syst. Sci. 2006, 115, 149-160. [CrossRef]

36. Bose, P.K.; Chaudhuri, A.K. Tide versus storm in epeiric coastal deposition: Two Proterozoic sequences, India. Geol. J. 1990, 25, 81-100. [CrossRef]

37. Gopalan, K.; Kumar, A.; Kumar, S.; Vijayagopal, B. Depositional history of the Upper Vindhyan succession, central India: Time constraints from $\mathrm{Pb}-\mathrm{Pb}$ isochron ages of its carbonate components. Precam. Res. 2013, 233, 108-117. [CrossRef]

38. Auden, J.B. Vindhyan sedimentation in the Son Valley, Mirzapur District. Geol. Surv. India 1933, 62, 141-150.

39. Banerjee, S.; Dutta, S.; Paikaray, S.; Mann, U. Stratigraphy, sedimentology and bulk organic geochemistry of black shales from the Proterozoic Vindhyan Supergroup (central India). J. Earth Syst. Sci. 2006, 115, 37-47. [CrossRef]

40. Banerjee, P.K.; Prakash, O. Galena mineralisation in the Vindhyan rocks of Amjhore, Sahabad district, Bihar, India. Econ. Geol. 1975, 70, 399-404. [CrossRef]

41. Guha, J. Sulfur isotope study of the pyrite deposit of Amjhore, Shahbad district, Bihar, India. Econ. Geol. 1971, 66, 326-330. [CrossRef]

42. Nair, N.; Ray, A. Syndepositional and diagenetic features in the pyrite ores of Amjhore, Bihar, India. Min. Depos. 1977, 12, 151-154. [CrossRef]

43. Valdiya, K.S. The Making of India: Geodynamic Evolution; Macmillan Publishers India Ltd.: Delhi, India, 2010; p. 816.

44. Singh, I. The Bijaigarh shale, Vindhyan system (Precambrian), India-An example of a lagoonal deposit. Sediment. Geol. 1980, 25, 83-103. [CrossRef]

45. Chakraborty, C. Gutter casts from the Proterozoic Bijaygarh Shale Formation, India: Their implication for storm-induced circulation in shelf settings. Geol. J. 1995, 30, 69-78. [CrossRef]

46. Bose, P.K.; Sarkar, S.; Chakrabarty, S.; Banerjee, S. Overview of the Meso- to Neoproterozoic evolution of the Vindhyan Basin, central India. Sed. Geol. 2001, 141, 395-419. [CrossRef]

47. Chakraborty, C. Proterozoic intracontinental basin: The Vindhyan example. J. Earth Syst. Sci. 2006, 115, 3-22. [CrossRef] 
48. Danyushevsky, L.; Robinson, P.; Gilbert, S.; Norman, M.; Large, R.; McGoldrick, P.; Shelley, M. Routine quantitative multi-element analysis of sulphide minerals by laser ablation ICP-MS: Standard development and consideration of matrix effects. Geochem. Explor. Environ. Anal. 2011, 11, 51-60. [CrossRef]

49. Jochum, K.P.; Pfänder, J.; Woodhead, J.D.; Willbold, M.; Stoll, B.; Herwig, K.; Amini, M.; Abouchami, W.; Hofmann, A.W. MPI-DING glasses: New geological reference materials for in situ $\mathrm{Pb}$ isotope analysis. Geochem. Geophy. Geosyst. 2005, 6, 1525-2027. [CrossRef]

50. Stepanov, A.; Danyushevsky, L.; Large, R.; Mukherjee, I.; Zhukova, I. deconvolution of the composition of fine-grained pyrite in sedimentary matrix by regression of time-resolved LA-ICP-MS data. Am. Mineral. 2020, 105, 820-832. [CrossRef]

51. Ireland, T.; Clement, S.; Compston, W.; Foster, J.; Holden, P.; Jenkins, B.; Lanc, P.; Schram, N.; Williams, I. Development of SHRIMP. Aus. J. Earth Sci. 2008, 55, 937-954. [CrossRef]

52. Crowe, D.E.; Vaughan, R.G. Characterization and use of isotopically homogeneous standards for in situ laser microprobe analysis of 34S/32S ratios. Am. Mineral. 1996, 81, 187-193. [CrossRef]

53. Farquhar, J.; Wing, B.A. The terrestrial record of stable sulphur isotopes: A review of the implications for evolution of Earth's sulphur cycle. In Mineral Deposits and Earth Evolution; McDonald, I., Boyce, A.J., Butler, I.B., Herrington, R.J., Polya, D.A., Eds.; Geological Society: London, UK, 2003; Volume 248, pp. 167-177.

54. Philippot, P.; Ávila, J.N.; Killingsworth, B.A.; Tessalina, S.; Baton, F.; Caquineau, T.; Muller, E.; Pecoits, E.; Cartigny, P.; Lalonde, S.V.; et al. Globally asynchronous sulphur isotope signals require re-definition of the Great Oxidation Event. Nat. Commun. 2018, 9, 2245. [CrossRef]

55. Baird, G.C.; Lash, G.G. Devonian strata and environments: Chautauqua County region. In 62nd Annual Meeting Guidebook; New York State Geological Association: New York, NY, USA, 1990; pp. A1-A46.

56. Baird, G.C.; Brett, C.E. Submarine erosion on the anoxic seafloor: Statinomic, paleoenvironmental, and temporal significance of reworked pyrite-bone deposits. In Modern and Ancient Continental Shelf Anoxia; Tyson, R.V., Pearson, T., Eds.; Geological Society of Special Publication: London, UK, 1991; Volume 58, pp. 233-257.

57. Wilkin, R.T.; Barnes, H.L.; Brantley, S.L. The size distribution of framboidal pyrite in modern sediments: An indicator of redox conditions. Geochim. Cosmo. Acta 1996, 60, 3897-3912. [CrossRef]

58. Lyons, T.W. Sulfur isotopic trends and pathways of iron sulfide formation in upper Holocene sediments of the anoxic Black Sea. Geochim. Cosmo. Acta 1997, 61, 3367-3382. [CrossRef]

59. Wignall, P.B.; Newton, R. Pyrite framboid diameter as a measure of oxygen deficiency in ancient mudrocks. Am. J. Sci. 1998, 298, 537-552. [CrossRef]

60. Schieber, J. Sedimentary features indicating erosion, condensation, and hiatuses in the Chattanooga Shale of central Tennessee: Relevance for sedimentary and stratigraphic evolution. In Mudstones and Shales 1: Basin Studies, Sedimentology and Paleontology; Schieber, J., Zimmerle, W., Sethi, P., Eds.; Schweizerbartsch Verlagsbuchhandlung: Stuttgart, Germany, 1998; pp. 187-215.

61. Schieber, J.; Baird, G. On the origin and significance of pyrite spheres in Devonian black shales of North America. J. Sed. Res. 2001, 71, 155-166. [CrossRef]

62. Formolo, M.J.; Lyons, T.W. Accumulation and Preservation of Reworked Marine Pyrite Beneath an Oxygen-Rich Devonian Atmosphere: Constraints from Sulfur Isotopes and Framboid Textures. J. Sed. Res. 2007, 77, 623-633. [CrossRef]

63. Rickard, D. Sulfidic sediments and sedimentary rocks. In Developments in Sedimentology; Van Loon, A.J., Ed.; Elsevier: Amsterdam, The Netherlands, 2012; p. 801.

64. Rickard, D.; Mussmann, M.; Steadman, J.A. Sedimentary Sulfides. Elements 2017, 13, 117-122. [CrossRef]

65. Pandalai, H.S.; Changkakoti, A.; Krouse, H.R.; Gunalan, N. The relationship between Carbon, Sulfur and Pyritic Iron in the Amjhore Deposit, Bihar, India. Econ. Geol. 1991, 86, 862-869. [CrossRef]

66. Schieber, J.; Sur, S.; Banerjee, S. Benthic microbial mats in black shale units from the Vindhyan Supergroup, Middle Proterozoic of India: The challenges of recognizing the genuine article. In Atlas of Microbial Mat Features Preserved within the Siliciclastic Rock Record; Schieber, J., Bose, P.K., Eriksson, P.G., Banerjee, S., Sarkar, S., Altermann, W., Catuneanu, O., Eds.; Elsevier BV: Amsterdam, The Netherlands, 2007; pp. 189-197.

67. Morse, J.W.; Luther, G.W., III. Chemical influences on trace metal-sulfide interactions in anoxic sediments. Geochim. Cosmochim. Acta 1999, 63, 3373-3378. [CrossRef] 
68. Partin, C.A.; Bekker, A.; Planavsky, N.J.; Scott, C.T.; Gill, B.C.; Li, C.; Podkovyrov, V.; Maslov, A.; Konhauser, K.O.; Lalonde, S.V.; et al. Large-scale fluctuations in Precambrian atmospheric and oceanic oxygen levels from the record of U in shales. Earth Planet. Sci. Lett. 2013, 369-370, 284-293. [CrossRef]

69. Bertine, K.K.; Koide, M.; Goldberg, E.D. Comparative marine chemistries of some trivalent metals-bismuth, rhodium and rare Earth elements. Mar. Chem. 1996, 53, 89-100. [CrossRef]

70. Taylor, S.R.; Mclennan, S.M. The geochemical evolution of the continental crust. Rev. Geophys. 1995, 33, 241-265. [CrossRef]

71. Crowe, S.A.; Døssing, L.N.; Beukes, N.J.; Bau, M.; Kruger, S.J.; Frei, R.; Canfield, D.E. Atmospheric oxygenation three billion years ago. Nature 2013, 501, 535-538. [CrossRef] [PubMed]

72. Planavsky, N.J.; Reinhard, C.T.; Wang, X.; Thomson, D.; McGoldrick, P.; Rainbird, R.H.; Johnson, T.; Fischer, W.W.; Lyons, T.W. Low Mid-Proterozoic atmospheric oxygen levels and the delayed rise of animals. Science 2014, 346, 635-638. [CrossRef] [PubMed]

73. Mishra, M.; Sen, S. Provenance, tectonic setting and source-area weathering of Mesoproterozoic Kaimur Group, Vindhyan Supergroup, Central India. Geol. Acta 2012, 10, 283-293.

74. Reimann, C.; De Caritat, P. Chemical Elements in the Environment, Fact Sheets for the Geochemist and Environmental Scientist; Springer: Berlin, Germany, 1998; p. 397.

(C) 2020 by the authors. Licensee MDPI, Basel, Switzerland. This article is an open access article distributed under the terms and conditions of the Creative Commons Attribution (CC BY) license (http://creativecommons.org/licenses/by/4.0/). 